\title{
The Interaction between Productivity and Export Behavior: Evidence from Chinese Electronics Firms
}

\author{
Xiaoyi Wu \\ Business School, Nanjing Normal University, Nanjing, China \\ Email: xywu@njnu.edu.cn
}

How to cite this paper: Wu, X. Y. (2020). The Interaction between Productivity and Export Behavior: Evidence from Chinese Electronics Firms. American Journal of Industrial and Business Management, 10, 1857-1869.

https://doi.org/10.4236/ajibm.2020.1012116

Received: December 3, 2020

Accepted: December 282020

Published: December 31, 2020

Copyright $\odot 2020$ by author(s) and Scientific Research Publishing Inc. This work is licensed under the Creative Commons Attribution International License (CC BY 4.0).

http://creativecommons.org/licenses/by/4.0/

\begin{abstract}
This paper explores the interaction between Chinese electronic firms' total factor productivity (TFP) and their export strategies, revealing there is a causal relationship between exporting and productivity growth. Based on the data of Chinese electronics firms in the period from 2005 to 2007, TFPs are estimated by a productivity estimator following Levinsohn-Petrin method. With propensity score matching, significant evidence which shows the mutual causal effect of firms' export activities and TFP growth can be found, supporting the trade models with firm heterogeneity by Chinese case.
\end{abstract}

\section{Keywords}

Productivity, Export, Heterogeneity, Electronics Firms

\section{Introduction}

In recent years, firms draw great attention for the role in international trade. New Trade Theory, represented by Paul Krugman, has been adopted to treat the homogeneity between firms. In the middle of the 1990s, Bernard and Jensen suggested it is firms heterogeneity that determines an enterprise exports or not by comparing the firm-level data of exporters and non-exporters. Particularly, productivity diversity links strongly to firm heterogeneity. Thus, the interaction between productivity and export behavior plays an important role in international trade issues, which mainly focuses on: 1) are export and productivity closely related? 2) Can export improve productivity? 3) Is it easier for firms with higher productivity to export? 4) Does higher productivity results in export for exporters or vice versa?

There are two hypotheses for explaining why exporters have a higher produc- 
tivity than non-exporters presented by Bernard \& Wagner (1997) and Bernard \& Jensen (1999), respectively. The former is known as self-selection effect, which considers firms with higher productivity may gain easier access to export market. Because in most cases, it is easier to find that exporters' productivity is higher than non-exports before exporting, as well as the growth rate of productivity. Exporting means extra costs for selling abroad including transportation expenses, distributing costs, marketing costs, human resource costs et al., all of which set a high entry threshold for less successful enterprises. Therefore, low productivity discourages a firm to export. Another hypothesis is learning-by-exporting effect. For new exporters, they can acquire experience quickly at the beginning in competitive international trades. Also, exchanging with partners and competitors may be beneficial to export smoothly. In general, firms learn by exporting through economies of scale, technology spillover and production factors reallocation.

Although both hypotheses are reasonable, empirical study is necessary to judge the interaction between productivity and export in line with local conditions. Our paper contributes to the literature by exploring specific interaction within Chinese electronics industry. We focus on electronics because multinational firms undertake a leading role of innovative characters in this sector, promoting rapid increase of TFP. And electronics sector has a high participation in international division and performs well in export market, occupying an average more than $10 \%$ of total export volume during 2005-2007. Working with a large firm-level data set over the period 2005-2007, we first estimate the TFP by Levinsohn-Petrin method in order to describe the TFP gap between exporters and non-exporters. Second, we use propensity score matching techniques in researching the casual interaction between export behavior and firm performance. Propensity score matching performs better in solving problems of endogeneity and selectivity and attrition bias than OLS. What we find is that potential exporters have higher TFP than non-exporters before exporting, and after entry into global market, exporters' performances are better than non-exporters in term of productivity. The interaction between productivity and export behavior displays as causality, supporting both hypotheses of self-selection effect and learning-by-exporting effect.

The rest of the paper is organized as follows. Section 2 will review the latest literature and evaluate the contribution. Section 3 describes the data and empirical methodology used for analyzing the interaction of exporting and productivity. The empirical findings are explained in Section 4, illustrating whether there is a causal effect of firm's exporting on TFP or vice versa.

\section{Background Literature}

Productivity has always been a central issue in economics, as it is related to source of sustainable economic growth. Since the 1990s, more and more scholars have been studying the productivity gap between firms following Bernard \& 
Jensen (1995), Clerides et al. (1998), Aw et al. (2000). The trade reality is that exporters and non-exporters exist in an industry at the same time, which can be explained by the productivity gap between firms. What is the interaction between productivity and export behavior? Existing literature shows that the interaction is based on assumption of causality. The two hypotheses, self-selection effect and learning-by-exporting effect, are amalgamated to illustrate the bidirectional causality.

Table 1 summarizes the sample and results from eleven typical studies of productivity and export using matching techniques since 2005. Self-selection effect points out that exporters have higher productivity than non-exporters, which does not result from export strategy, but from the survival of the fittest. Despite diversity in sample, most report that exporters are more productive than non-exporters before entry to export market, which is consistent with the hypothesis self-selection effect.

While a few studies report that there is "Productivity Paradox", which means the productivity performance of exporters and non-exporters are similar. The firm-level productivity shows no evidence for pre-entry and post-entry difference, antagonistic to self-selection effect, see for example Greenaway et al. (2005).

Table 1. Micro-empirical Research of Productivity and Exporting With a Matching Approach.

\begin{tabular}{|c|c|c|c|c|c|}
\hline \multirow[b]{2}{*}{ Authors } & \multirow[b]{2}{*}{ Country } & \multirow[b]{2}{*}{ Sample } & \multicolumn{3}{|l|}{ Results } \\
\hline & & & Self-selection & $\begin{array}{l}\text { Learning-by- } \\
\text { exporting }\end{array}$ & $\begin{array}{l}\text { Productivity } \\
\text { Paradox }\end{array}$ \\
\hline Arnold \& Hussinger (2005) & Germany & 2149 observations; 389 firms; $1992-2000$ & & $x$ & $x$ \\
\hline Fryges \& Wagner (2008) & Germany & $\begin{array}{l}\text { Mining and manufacturing industries; } \\
1995-2005\end{array}$ & - & $\sqrt{ }$ & $x$ \\
\hline Serti \& Tomasi (2008) & Italy & 38,771 firms; 1989-1997 & $\sqrt{ }$ & $\sqrt{ }$ & $x$ \\
\hline Greenaway et al. (2005) & Sweden & $\begin{array}{l}\text { 36,903 observations; } 3570 \text { firms; } \\
\text { 1980-1997 }\end{array}$ & $x$ & $\times$ & $\sqrt{ }$ \\
\hline Eliasson et al. (2012) & Sweden & SMEs; 1997-2006 & $\sqrt{ }$ & $\times$ & $x$ \\
\hline Aldan \& Gunay (2008) & Turkey & $\begin{array}{l}\text { 41,463 observations; } 4498 \text { firms; } \\
1989-2003\end{array}$ & $\sqrt{ }$ & $\sqrt{ }$ & $x$ \\
\hline Yang \& Mallick (2010) & China & 2340 firms; 2000-2002 & $\sqrt{ }$ & $\sqrt{ }$ & $x$ \\
\hline Ranjan \& Raychaudhuri (2011) & India & 3698 firms; 1990-2006 & $\sqrt{ }$ & $\sqrt{ }$ & $x$ \\
\hline Haidar (2012) & India & 33,510 firms; 1991-2004 & $\sqrt{ }$ & $x$ & $x$ \\
\hline Sharma \& Mishra (2015) & India & manufacturing firms; 1994-2006 & $\sqrt{ }$ & $\sqrt{ }$ & $x$ \\
\hline Kasahara \& Lapham (2013) & Chile & $\begin{array}{l}\text { manufacturing firms with at least } 10 \\
\text { employees; 1990-1996 }\end{array}$ & - & $\sqrt{ }$ & - \\
\hline Benkovskis et al. (2019) & $\begin{array}{l}\text { Latvia and } \\
\text { Estonia }\end{array}$ & $\begin{array}{l}\text { Latvian frms; 2006-2015; and Estonian } \\
\text { frms;1995-2014 }\end{array}$ & - & $\sqrt{ }$ & - \\
\hline Bigsten \& Gebreeyesus (2007) & Ethiopia & Manufacturing industries; 1996-2005 & $\sqrt{ }$ & $\sqrt{ }$ & $x$ \\
\hline Kandilov \& Liu (2011) & Colombia & $\begin{array}{l}\text { around } 4500 \text { firms of agri food industry; } \\
1981-1987\end{array}$ & ; & $\sqrt{ }$ & $\times$ \\
\hline
\end{tabular}

Note: “-” means not involved in the research. 
Another hypothesis learning-by-exporting effect, just as its name implies, means export strategy boosts firms' productivity, though economies of scale, technology spillovers and production factors reallocation. There is a growing body of evidence for learning effect, see for Fryges \& Wagner (2008), Serti \& Tomasi (2008), Aldan \& Gunay (2008), Yang \& Mallick (2010), Ranjan \& Raychaudhuri (2011), Bigsten \& Gebreeyesus (2007), Kandilov \& Liu (2011), Sharma \& Mishra (2015), Kasahara \& Lapham (2013), Benkovskis et al. (2019). On the other hand, Arnold \& Hussinger (2005), Eliasson et al. (2012) and Haidar (2012) do not find significant evidence for learning effect from exporting, respectively for Germany, Sweden and India. On the whole, samples of developing countries in support of learning-by-exporting effect occupy a larger proportion than those of developed countries.

As a developing country, China regards export-led growth as a good form of growth. China's export sales have ranked first since 2010. Product mix is optimizing, given priority to manufactured goods, especially electronic products. So both theoretical and empirical literature of China's situation has emerged. Kraay (1999) is one of the earliest research which use Chinese industrial enterprises' data to investigate export and firm performance. By dynamic panel data estimation of Chinese data over 1988-1992, controlling for past firm performance and unobserved characteristics, the paper finds that past export behavior leads to improvements in firm productivity, confirming the existence of causal relationship between export and productivity growth. Wang et al. (2009) use Chinese firm data from 1997 to 2000 to examine whether exporters are more productive and whether export strategies promote the productivity. The results are supportive evidence for learning-by-exporting effects rather than self-selection effects. Yang \& Mallick (2010) evaluates Chinese firms' self-selection and learning-by-exporting with data from WBIC over the period 2000-2002. Robust to three matching methods using difference-in-difference estimator, the paper finds firms are self-selected into export markets and gain additional TFP growth from learning-by-exporting effect.

It must be noted, however, that there are few empirical studies about export and productivity of Chinese electronics sector. So this paper contributes to the literature in important ways. Firstly, we study the interaction of export activities and TFP growth using a matching approach, which enables us to compare the outcome variable of treated sample and the sample supposing the treated were not treated. Second, it describes firm performance and export status of one of the industry segmentation that is the electronics industry. In the reminder of this paper, we study both hypotheses of self-selection effect and learning-by-exporting effect in data of Chinese electronics firms.

\section{Data and Methodology}

In this study, the data is from China Industrial Enterprises Database, 2005 to 2007. We consider firms with at least 10 employees in order to control company 
size. And firms should keep exporting during the observation period, so statistical error can be avoided. Exceptional values and repeating values are removed before estimation. Our processed data set contains 8186 firms over the period 2005-2007, yielding a maximum of 24,558 observations. The electronics industries in the database are scattered into three main categories, namely H39 Electronic equipment and machinery, H40 Communication equipment, computers and other electronic equipment, and H41 Instrumentation and Office Machinery. Specifically, there are eleven subclasses composing the electronic industry we study in this paper, including 1) Household electronic appliances; 2) Communications equipment; 3) Rader; 4) Broadcast and TV; 5) Computers; 6) Electronic devices; 7) Electronic components; 8) Home Audio and Video equipment; 9) Other electronic equipment; 10) General instrument; 11) Special instrument.

In Table 2 we summarize the main features of the 8186 firms. The treated group refers to the group of exporters, whose value of export is no less than 10,000 RMB by our definition. Control group means the group of non-exporters, who are mainly for the domestic market. Export enterprises account for about 55\% of our total observations. The table clearly shows that the exporters' characteristics in the left column are larger than that of non-exporters in the right column. T-test obtains the significance of different characteristics of the two groups. Exporters tend to have higher TFP of 5.4770 and more output of 11.3742 . They are willing to have more employees of 5.8602 and more capital of 3.6122, pay more wage of 2.9540, and have more Intermediate Inputs of 11.0364. Also, exporters relatively live longer of 9.2205 than non-exporters, though not quite significant.

This paper applies Levinsohn-Petrin productivity estimator for total factor productivity estimation and propensity score matching to analyze the existence of self-selection effect and learning-by-exporting effect.

The measurement of firm productivity in this study is total factor productivity (TFP, hereafter). A key issue for TFP estimation is the correlation between unobservable productivity shocks and production inputs. The bias in TFP estimation is mainly simultaneity bias and selectivity and attrition bias, which make OLS not applicable. Levinsohn \& Petrin (2003) uses intermediate inputs as proxies to develop an estimator, the production technology is assumed to be Cobb-Douglas of the form: $y_{i, t}=\beta_{0}+\beta_{l} l_{i, t}+\beta_{k} k_{i, t}+\beta_{m} m_{i, t}+\omega_{i, t}+\eta_{i, t}$, where $y_{i, t}$ represents the logarithm output of firm $i$ in period $t$, measured as gross revenue in this paper; $l_{i, t}$ and $k_{i, t}$ are logarithm inputs of labor and capital respectively; and $m_{i, t}$ is the logarithm intermediate input. The residuals have a two-part structure, one part $\omega_{i, t}$ representing TFP, and the other part $\eta_{i, t}$ is error term. TFP estimation by Levinsohn-Petrin productivity estimator has two steps. Firstly, we need to construct a third order polynomial including $k_{i, t}$ and $m_{i, t}$. Then we should estimate $\hat{\phi}\left(k_{i, t}, m_{i, t}\right)$, the coefficient of $k_{i, t}$ and $m_{i, t}$. Finally we find the solution according to optimality condition.

Figure 1 shows the probability density distribution of TFP during 2005-2007. The solid line refers to exporters, and the dotted line refers to non-exporters. As 
Table 2. Descriptive statistics of electronics Firms from 2005 to 2007.

\begin{tabular}{cccccccc}
\hline \multirow{2}{*}{ Variable } & \multicolumn{3}{c}{ Treated Group } & \multicolumn{3}{c}{ Control Group } & t-Test \\
\cline { 2 - 8 } & Mean & Std.Dev & obs. & Mean & Std.Dev & Obs. & Diff. in Mean \\
\hline TFP & 5.4770 & 0.7747 & 13,394 & 5.0424 & 0.6397 & 11,114 & $0.4346^{* * *}$ \\
Output & 11.3742 & 1.6736 & 13,403 & 10.3038 & 1.2447 & 11,145 & $1.0704^{\star * *}$ \\
Employment & 5.8602 & 1.2665 & 13,403 & 4.7872 & 1.0330 & 11,155 & $1.0730^{* * *}$ \\
Capital Per Worker & 3.6122 & 1.3582 & 13,395 & 3.3314 & 1.3751 & 11,125 & $0.2808^{* * *}$ \\
Wage Per Worker & 2.9540 & 0.5640 & 13,403 & 2.8208 & 0.5951 & 11,151 & $0.1332^{\star * *}$ \\
Intermediate Inputs & 11.0364 & 1.7199 & 13,402 & 9.9205 & 1.3541 & 11,142 & $1.1158^{* * *}$ \\
Firm Age & 9.2205 & 6.2005 & 13,403 & 9.1978 & 7.5904 & 11,155 & 0.0227 \\
\hline
\end{tabular}

Note: Firm age means the number of years since establishment, with extreme values dropped.

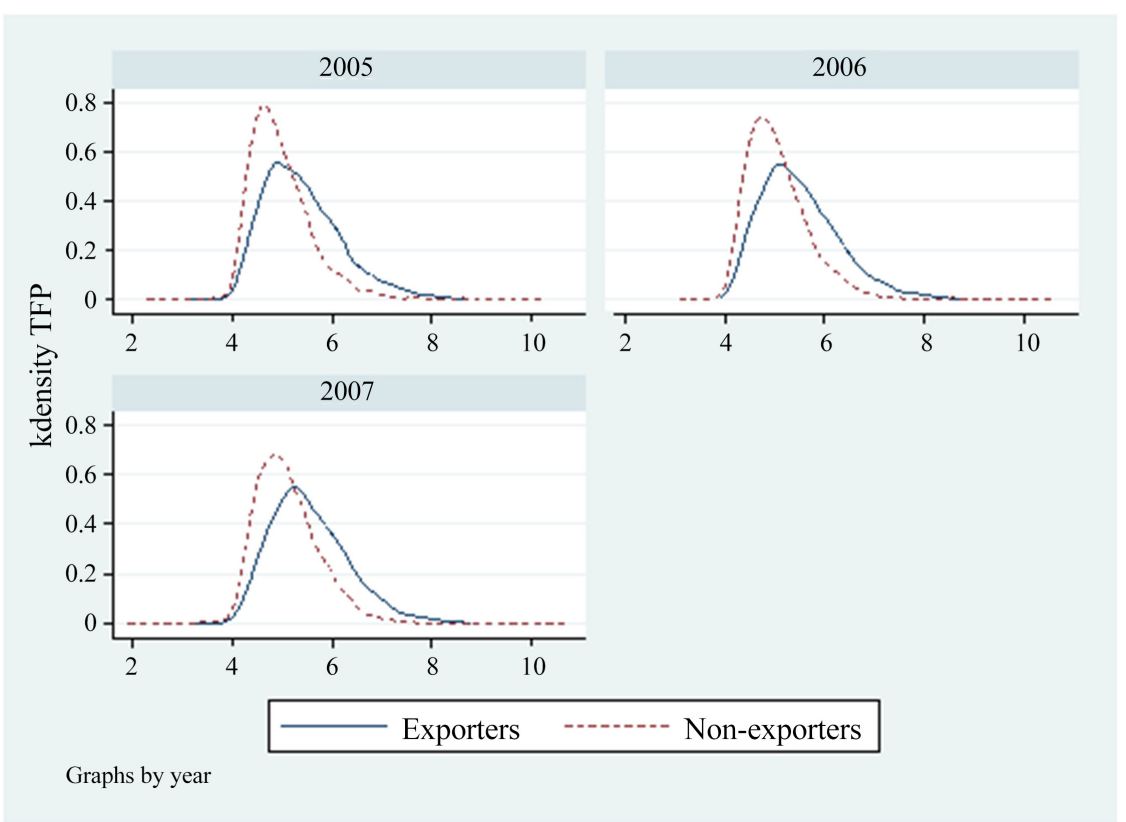

Figure 1 . TFP kdensity by year.

shown in the figure, TFP is increasing year after year. And exporters' TFP is higher and more agglomerating in distribution than that of non-exporter. From a rough description we can see exporters have a productivity advantage over non-exporters, but to study the causality of export status and productivity situation, it requires a particular technique, that is propensity score analysis.

The Interaction between Productivity and Exporting is essentially a causal inference. Common models for causality are Rubin Causal Model (RCM) and Causal Diagram. And RCM is more accurate for application. In a two-value situation, we assume $Z_{i}$ means whether individual $i$ is treated, $Z_{i}=1$ if treated, and $Z_{i}=0$ if not treated. $Y_{i}$ is the outcome variable of individual $i$. Denote $\left(Y_{i}(1), Y_{i}(0)\right)$ as potential result of treatment situation of individual $i$, and $Y_{i}(1)-Y_{i}(0)$ is the treatment causal effect of individual $i$. Each Individual is ei- 
ther treated or controlled. So $\left(Y_{i}(1), Y_{i}(0)\right)$ must be missing half, and individual causal effect is unrecognizable. However, with the randomization of $Z$, average causal effect (ACE) is recognizable.

$$
\begin{aligned}
\operatorname{ACE}(Z \rightarrow Y) & =E\left(Y_{i}(1)\right)-E\left(Y_{i}(0)\right) \\
& =E\left(Y_{i}(1) \mid Z_{i}=1\right)-\left(Y_{i}(0) \mid Z_{i}=0\right) \\
& =E\left(Y_{i} \mid Z_{i}=1\right)-\left(Y_{i} \mid Z_{i}=0\right)
\end{aligned}
$$

where the second formula brings to randomization, that is $Z \perp(Y(1), Y(0))$ ( $\perp$ means independence).

Propensity score is one of the existing methods to estimate treatment effect in observational studies. Rosenbaum \& Rubin (1983) put forward propensity score matching, which is a technique for reducing the dimensionality of complex data sets. Propensity score is defined as $e(X)=P(Z=1 \mid X)$. The properties include the following: 1) $X \perp Z \mid e(X)$; 2) If the strongly ignorable treatment assignment assumption holds and $0<e(X)<1$, that is $Z \perp(Y(1), Y(0)) \mid e(X)$ and $0<e(X)<1$. So if we can observe both treated result and untreated result of one sample, the difference of the results can be used to evaluate causal effect of the treatment. While in reality, each sample only has one condition, so the unobservable condition is a virtual result. We define $W$ as an indicator variable of treatment. If treated, $W=1 ; W=1$, if not, $W=0 . Y$ is the outcome variable of treatment. $Y_{1}$ is treated result, and $Y_{0}$ is untreated result. So we need to estimate the difference $\left(Y_{1}-Y_{0}\right)$. Rosenbaum \& Rubin (1983) define it as Average Treatment Effect (ATE): ATT $\equiv E\left(Y_{1}-Y_{0}\right)$. If the samples contain any sample which cannot accept treatment or has no condition for treatment, the ATE estimator is biased (Heckman et al., 1997). So another estimator is introduced: Average Treatment Effect for the Treated (ATT): ATT $\equiv E\left(Y_{1}-Y_{0} \mid w=1\right)$.

In practice, estimation has two stages. The first stage is to fit a Logistic/Probit Model, and estimate the propensity score $\hat{e}(X)$ of each individual. The second stage is to estimate corresponding ATTs by hierarchical $\hat{e}(X)$. In this paper, we adopt two matching methods to match firms: kernel matching and three nearest neighbors matching. A central feature of kernel matching is the application of nonparametric regression, which can smooth unknown functions. Kernel matching allows estimation of treatment effects for the treated to use information of all possible controls. The approach can perform one-to-many matching by calculating the weighted average of the outcome variables for the control group, and comparing the weighted average with that of the treated group. The kernel matching can be expressed as: $\mathrm{ATT}=\frac{1}{n_{1}} \sum_{i \in I_{1} \cap s_{p}}\left[Y_{1 i}-\sum_{j \in I_{0} \cap s_{p}} W(i, j) Y_{0 j}\right]$, where $n_{1}$ is the number of treated; $I_{0}$ and $I_{1}$ are the set of indices for controls and program participants respectively, $Y_{0}$ and $Y_{1}$ are the outcomes of control group and treated group respectively, so term $\sum_{j \in I_{0} \cap S_{p}} W(i, j) Y_{0 j}$ measures the weighted average of the outcome for all non-treated, which match to participant 
$i$ on the propensity score differentially. And $W(i, j)$ is the weight or distance on propensity score between $i$ and $j$. The method of constructing the weighted mean using kernel functions is called the kernel estimator, which gives greater weight to the closest neighbors and less weight to distant points. The main results in this paper are based on kernel estimator with a bandwidth of 0.06. In contrast to the kernel estimator, nearest neighbor matching, as one method of greedy matching, is more straightforward. It can be expressed as:

$C\left(P_{i}\right)=\min _{j}\left\|P_{i}-P_{j}\right\|, j \in I_{0}$, where $I_{0}$ and $I_{1}$ are the set of control and treated participants respectively, $P_{i}$ and $P_{j}$ are the propensity scores of treated and control participants respectively. $C\left(P_{i}\right)$ means a neighborhood that contains a control participant $j$ as a match for treated participant $i$, if the absolute value of propensity scores difference is the smallest among all the pairs between $i$ and $j$. The three nearest neighbor matching allows three units from the control group to match a treated participant. It is the second method used in this paper for robustness. The detailed results of Chinese electronics industry are in the following chapter.

\section{The Interaction between Productivity and Exporting: Empirical Results}

As mentioned above, in the first stage we conduct a probit model to estimate the propensity scores of the observations. The exogenous covariates of the probit model include the firm size (measured by the logarithmic number of employees), the (logarithm of the) average wage per employee, the (logarithm of the) average capital per employee, firms' (logarithmic) TFP, firm age and a dummy variable indicating the firms' registration types, which are firms of Chinese mainland capital, firms of Hongkong-Macau-Taiwan capital and firms of foreign capital. Furthermore, the interactions with average wage per employee and TFP, average wage per employee and firm age, average capital per employee and firm age are introduced into the probit model (Table 3). Our observation period is 2005-2007, which means the period is from year $\mathrm{t}-2$ to year $\mathrm{t}$. Considering that the mutual interaction between productivity and export Behavior may be a gradual process with hysteresis effect, we study self-selection effect of both one year and two years before entry into international market with current export conditions and firm performance variables of year $t-1$ and $t-2$, and learning-by-exporting effect of both one year and two years after entry with current firm performance variables and export conditions of year $t-1$ and $t-2$.

The second stage is to estimate corresponding ATT values. Table 4 shows the ATTs by the two matching techniques of both self-selection effect and learning-by-exporting effect in the first column. The second column contains the $\mathrm{t}$-test results that indicate whether there are significant differences in a given covariate between matched treated group and control group. The last two columns are the numbers of participants of treated group and untreated group respectively. 
Table 3. Variables definition and description for probit models.

\begin{tabular}{lllllll}
\hline \multirow{2}{*}{ Variable } & 2005 & \multicolumn{3}{c}{2006} & \multicolumn{2}{c}{2007} \\
\cline { 2 - 7 } & Mean & Std.Dev. & Mean & Std.Dev. & Mean & Std.Dev. \\
\hline Export Status Dummy & 0.5377 & 0.4986 & 0.5457 & 0.4979 & 0.5539 & 0.4971 \\
Log TFP & 5.2001 & 0.7421 & 5.2918 & 0.7468 & 5.3476 & 0.7494 \\
Size (Log Nunber of Employees) & 5.3175 & 1.2677 & 5.3887 & 1.2824 & 5.4123 & 1.2963 \\
Log Capital Per Employee & 3.4457 & 1.3823 & 3.4906 & 1.3660 & 3.5182 & 1.3698 \\
Log Wage Per Employee & 2.7348 & 0.5697 & 2.8970 & 0.5631 & 3.0487 & 0.5706 \\
Firm Age & 9.2471 & 6.9052 & 9.2101 & 6.8716 & 9.1735 & 6.8235 \\
Registration Dummy & & & & & & \\
Chinese Mainland Capital & 0.5100 & 0.4999 & 0.5103 & 0.4999 & 0.5083 & 0.5000 \\
Hongkong-Macau-Taiwan Capital & 0.2414 & 0.4280 & 0.2408 & 0.4276 & 0.2420 & 0.4283 \\
Foreign Capital & 0.2486 & 0.4322 & 0.2490 & 0.4324 & 0.2497 & 0.4329 \\
Interaction Terms & & & & & & \\
(Log TFP)*(Log Wage Per Employee) & 14.3760 & 4.3121 & 15.4902 & 4.4766 & 16.4837 & 4.6829 \\
(Log Wage Per Employee)*(Firm age) & 25.5429 & 20.3394 & 26.7703 & 20.9435 & 28.0562 & 21.6060 \\
(Log Capital Per Employee)*(Firm age) & 32.7155 & 30.9864 & 32.8764 & 30.7819 & 32.9554 & 30.7660 \\
\hline & & & & & & \\
\hline
\end{tabular}

Table 4. Matching results.

\begin{tabular}{|c|c|c|c|c|}
\hline & ATT & T-stat & Treated & Untreated \\
\hline \multicolumn{5}{|c|}{ Self-selection (Two Years Before Entry) } \\
\hline Kernel & $0.0651^{\star *}$ & 2.08 & 1933 & 768 \\
\hline Three Nearest Neighbors & $0.0855^{\star * *}$ & 2.62 & 1933 & 768 \\
\hline \multicolumn{5}{|c|}{ Self-selection (One Year Before Entry) } \\
\hline Kernel & 0.0750 * & 1.84 & 728 & 469 \\
\hline Three Nearest Neighbors & $0.1012^{* *}$ & 2.39 & 728 & 469 \\
\hline \multicolumn{5}{|c|}{ Learning-by-exporting (One Year After Entry) } \\
\hline Kernel & $0.0690 * *$ & 2.47 & 1496 & 976 \\
\hline Three Nearest Neighbors & $0.0685^{* *}$ & 2.34 & 1496 & 976 \\
\hline \multicolumn{5}{|c|}{ Learning-by-exporting (Two Years After Entry) } \\
\hline Kernel & $0.0715^{* * *}$ & 4.21 & 6148 & 2438 \\
\hline Three Nearest Neighbors & $0.0875^{\star * *}$ & 4.80 & 6148 & 2438 \\
\hline
\end{tabular}

Note: ${ }^{\star}{ }^{* *},{ }^{* *}$ indicate statistical significance at $10,5,1$ percent level respectively.

Looking at the ATTs, we find that result of two years before entry from kernel matching indicates that exporters tend to have 6.51 percent higher TFP than non-exporters, and the corresponding result of one year before entry is 7.50 percent higher TFP. It also indicates that before firms' entry into foreign market, the productivity differences between potential exporters and non-exporters get bigger. One possible explanation is that there are additional costs for product 
sales in foreign countries, including transportation costs, marketing costs, labor costs of the foreign network, and products improvement costs, all of which form a barrier to entry. Potential export enterprises must continuously improve their productivity to overcome the barrier. While less successful enterprises are unable to overcome the barrier. So exporters usually have a higher TFP growth rate than non-exporters before entry, resulting in the wider productivity gap. Therefore, we find evidence showing that exporters are more productive than non-exporters, proving the existence of hypothesis of self-selection effect in Chinese electronics sector.

Now considering the hypothesis of learning by exporting effect, results of one year and two years after entry turn out that exporters have respectively 6.90 and 7.15 percent higher TFP than non-exporters by kernel matching, showing firms have TFP growth continuously from learning effect in our observation period. Exporters can take the opportunity to compete with foreign companies through exporting. And competition is one of the most effective means for technology transfer and structural adjustment. Exporters can learn from foreign firms in core technique and product $\mathrm{R} \& \mathrm{D}$. As a result, it is proved that learningby-exporting effect is significantly existed and has a strong influence on export enterprises.

To ensure the robustness of the results, this paper also uses another matching technique, Three Nearest Neighbors Matching, for self-selection effect and learning-by-exporting effect testing. It also reaches similar outcomes and trends with Kernel matching, positive ATT values and wider productivity gap between exporters and non-exporters with export growth. T-test shows that all differences are significant. So the estimation results of different methods show good robustness. Evidence has been shown in this paper that the self-selection effect and learning-by-exporting effect on productivity are remarkably existing in Chinese electronics sector.

\section{Conclusion}

In this paper, we analyze the interaction between Chinese electronic firms' TFP and their export strategies by a causal relationship test. We find that there is a causal relationship between exporting and productivity growth-at least in Chinese electronics industry. Firms' TFPs are estimated by a productivity estimator following Levinsohn \& Petrin (2003). Electronic exporters' average TFP is higher and than that of non-exporter, premising self-selection effect. In our model of propensity score, TFP growth increases the probability of firms' export behavior. Meanwhile, firms participating in global division surpass those serve domestic market in the aspect of productivity.

Two different matching methods are used in this paper, including kernel matching and three nearest neighbor matching, reaching a consistent conclusion. With data of 8186 Chinese electronic firms in the period 2005-2007, results based on kernel matching show that potential exporters have an average 7.00 
percent higher TFP than non-exporters in last two years before entry. On the other hand, in the following two years after exporting, exporters have an average 7.03 percent higher TFP than non-exporters, indicating continuous productivity growth. Robust to different matching approach, our findings confirm the mutual directions of causality between exporting and productivity, that is the good ones go global, and gain an ego boost. According to the results, the hypotheses seem appropriate for Chinese electronic case, supporting heterogeneous firms model of Melitz (2003).

The significant existence of self-selection effect and learning-by-exporting effect in Chinese electronics sector contributes to a new understanding of the role that export plays to economic growth from the perspective of productivity. Exporting has been one of the driving forces for China's economy growth by boosting firms' productivity levels. With the deepening of economic globalization and fierce competition in international trade, exporting can promote Chinese enterprises to take advantage to upgrade technology, optimize production structure and improve product quality by both self-selection effect and learning-by-exporting effect, continuously improving the competitiveness of Chinese firms. Therefore, given balanced import and export trade policy as a starting point, China will need to continue with stabilizing and expanding exports in the future with firm-level evidence from electronics industry.

\section{Conflicts of Interest}

The author declares no conflicts of interest regarding the publication of this paper.

\section{References}

Aldan, A., \& Gunay, M. (2008). Entry to Export Markets and Productivity: Analysis of Matched Firms in Turkey. The Central Bank of the Republic of Turkey, Research and Monetary Policy Department Working Paper, No. 08/05.

Arnold, J. M., \& Hussinger, K. (2005). Export Behavior and Firm Productivity in German Manufacturing: A Firm-Level Analysis. Review of World Economics, 141, 219-243. https://doi.org/10.1007/s10290-005-0026-8

Aw, B. Y., Chung, S., \& Roberts, M. J. (2000). Productivity and Turnover in the Export Market: Micro-Level Evidence from the Republic of Korea and Taiwan (China). World Bank Economic Review, 14, 65-90. https://doi.org/10.1093/wber/14.1.65

Benkovskis, K., Masso, J., Tkacevs, O., Vahter, P., \& Yashiro, N. (2019). Export and Productivity in Global Value Chains: Comparative Evidence from Latvia and Estonia. Review of World Economics, 156, 557-577. https://doi.org/10.1007/s10290-019-00371-0

Bernard, A. B., \& Jensen, J. B. (1995). Exporters, Jobs, and Wages in U.S. Manufacturing, 1976-1987 (pp. 67-119). Brookings Papers on Economic Activity, Washington DC: Brookings. https://doi.org/10.2307/2534772

Bernard, A. B., \& Jensen, J. B. (1999). Exceptional Exporter Performance: Cause, Effect, or Both? Journal of International Economics, 47, 1-25.

https://doi.org/10.1016/S0022-1996(98)00027-0 
Bernard, A. B., \& Wagner, J. (1997). Exports and Success in German Manufacturing. Weltwirtschaftliches Archiv/Review of Word Economics, 133, 134-157. https://doi.org/10.1007/BF02707680

Bigsten, A., \& Gebreeyesus, M. (2007). The Small, the Young, and the Productive: Determinants of Manufacturing Firm Growth in Ethiopia. Economic Development and Cultural Change, 55, 813-840. https://doi.org/10.1086/516767

Clerides, S. K., Lach, S., \& Tybout, J. R. (1998). Is Learning by Exporting Important? Micro-Dynamic Evidence from Colombia, Mexico, and Morocco. Quarterly Journal of Economics, 113, 903-947. https://doi.org/10.1162/003355398555784

Eliasson, K., Hansson, P., \& Lindvert, M. (2012). Do Firms Learn by Exporting or Learn to Export? Evidence from Small and Medium-Sized Enterprises. Small Business Economics, 39, 453-472. https://doi.org/10.1007/s11187-010-9314-3

Fryges, H., \& Wagner, J. (2008). Exports and Productivity Growth: First Evidence from a Continuous Treatment Approach. Review of World Economics, 144, 695-722. https://doi.org/10.1007/s10290-008-0166-8

Greenaway, D., Gullstrand, J., \& Kneller, R. (2005). Exporting May Not Always Boost Firm Level Productivity. Review of World Economics/Weltwirtschaftliches Archiv, 141, 561-582. https://doi.org/10.1007/s10290-005-0045-5

Haidar, J. I. (2012). Trade and Productivity: Self-Selection or Learning-by-Exporting in India. Economic Modelling, 29, 1766-1773. https://doi.org/10.1016/j.econmod.2012.05.005

Heckman, J., Ichimura, H., \& Todd, P. (1997). Matching as an Econometric Evaluation Estimator. Review of Economic Studies, 65, 261-294. https://doi.org/10.1111/1467-937X.00044

Kandilov, I. T., \& Liu, X. (2011). Do Exports Raise Productivity? Plant-Level Evidence from the Colombian Agri-Food Industries. 2011 Annual Meeting, Pittsburgh, 24-26 July 2011, 1-19.

Kasahara, H., \& Lapham, B. (2013). Productivity and the Decision to Import and Export: Theory and Evidence. Journal of International Economics, 89, 297-316. https://doi.org/10.1016/j.jinteco.2012.08.005

Kraay, A. (1999). Exports and Economic Performance: Evidence from a Panel of Chinese Entreprises. Washington DC: World Bank.

Levinsohn, J., \& Petrin, A. (2003). Estimating Production Functions Using In-Puts to Control for Unobservables. Review of Economic Studies, 70, 317-341. https://doi.org/10.1111/1467-937X.00246

Melitz, M. J. (2003). The Impact of Trade on Intra-Industry Reallocations and Aggregate Industry Productivity. Econometrics, 71, 1695-1725. https://doi.org/10.1111/1468-0262.00467

Ranjan, P., \& Raychaudhuri, J. (2011). Self-Selection VS Learning: Evidence from Indian Exporting Firms. Indian Growth and Development Review, 4, 22-37. https://doi.org/10.1108/17538251111124981

Rosenbaum, P., \& Rubin, D. B. (1983). The Central Role of the Propensity Score in Observational Studies for Causal Effects. Biometrika, 70, 41-55.

https://doi.org/10.1093/biomet/70.1.41

Serti, F., \& Tomasi, C. (2008). Self-Selection and Post-Entry Effects of Exports: Evidence from Italian Manufacturing Firms. Review of World Economics, 144, 660-694. https://doi.org/10.1007/s10290-008-0165-9

Sharma, C., \& Mishra, R. K. (2015). International Trade and Performance of Firms: Un- 
raveling Export, Import and Productivity Puzzle. The Quarterly Review of Economics and Finance, 57, 61-74. https://doi.org/10.1016/j.qref.2015.02.001

Wang, H., Yang, J., \& Lai, M. (2009). Export Behavior and Firm Productivity in China. Journal of Chinese Economic and Business Studies, 7, 409-428. https://doi.org/10.1080/14765280903332223

Yang, Y., \& Mallick, S. (2010). Export Premium, Self-Selection and Learning-by-Exporting: Evidence from Chinese Matched Firms. The World Economy, 33, 1218-1240.

https://doi.org/10.1111/j.1467-9701.2010.01277.x 